\title{
Nigger: Notes from a New Orleans Daughter
}

\author{
I saw cotton and I saw black \\ Tall white mansions and little shacks. \\ Southern man when will you pay them back? \\ -Neil Young, "Southern Man"
}

I have been asked to write something about race and New Orleans, the assumption being that I know something about race and New Orleans since I was born and raised in that city. It is, I think, a somewhat false assumption, but one I have faced often since I moved away from Louisiana as an adult and found myself living in the rural Midwest. The farther south you are, the common wisdom goes, the more racist you are, and now look at all these photographs and images from Katrina. Doesn't it prove what everyone always suspected, that New Orleans is the worst of the worst?

No matter that the abstract for my lowa house reproduces twice (once when the home was sold in the 1930s and again in the 1940s), the original owner's apparently legal directive that no black buy or live in the home. No matter that the city council in Galesburg, Illinois, where I lived for several years, voted down about eight years ago-unanimously and without discussion-a resolution that would have made it illegal to discriminate against renters because of their sexual preferences; no matter that my neighbors in Illinois stopped speaking to me when I openly dated a black man; no matter that the Illinois policeman who helped the kids in my son's school cross the street confided in me one day about how unhappy he was regarding the niggers who had moved in down the street; in the minds of the general public, and even some of my colleagues at the non-southern universities and colleges where I have taught, race is primarily a southern problem.

The southern rock band Lynyrd Skynyrd famously responded to Canadian Neil Young's accusations of racism in his "Southern Man" with a song of their own, "Sweet Home Alabama": "Well, I hope Neil Young will remember/a southern man don't need him around anyhow." Their critique was for his sweeping generaliza- 
tion; Young's song seems to suggest that all southerners are racist. Both songs have become popular emblems of either side of the race dispute, and have an eerie personal connection for me as well. Neil Young, the liberal intellectual's singer songwriter, was a favorite of mine, and Lynyrd Skynyrd, the working class, whiskey-drinking group, was my brother Andre's favorite band.

Andre died unexpectedly a few weeks before Katrina hit. Like many New Orleans working class men of his generation-he was born in 1964-he died conflicted about issues of race. My brother was clearly prejudiced against blacks; my mother called him racist and fought with him bitterly about his views, but the man who cried most at my brother's funeral, the man he paid well to work for him for ten years in the small body shop he owned, the man who was one of his favorite drinking companions, was a black man.

Things are not always what they seem, and often are more complicated than they seem. It turns out Neil Young was a big Skynyrd fan. Skynyrd's lead singer Ronnie Van Zant wore a Neil Young shirt on stage during the last two years of his life and supposedly was wearing one when he died. Van Zant grew up in Shantytown, a ghetto on the west side of Jacksonville, one of the few parts of town that wasn't segregated. In response to charges of racism in the band's lyrics, he said "We're southern rebels, but more than that, we know the difference between right and wrong."

I was born and raised a white woman in a city that is almost $70 \%$ black. There is no doubt that the black culture had a profound influence on me. Mostly food and music, but food and music are religions in New Orleans, and are still twin gods of my sky. I grew up with a mother who loved music, especially music with soul, so my spiritual teachers were Mahalia Jackson, Sydney Bechet, Louis Armstrong, Irma Thomas, Clarence Gatemouth Brown and Professor Longhair among others. The gumbo we ate every Sunday is unimaginable without the African contributions of okra and cayenne, indeed the word gumbo comes from gombo, the African word for okra. I learned, from the listening, watching and cooking I did as a young woman a certain way of being in the world, a way that respected things sensual, a way that was unafraid of speaking or singing sorrow, a way that saw a certain kind of cooking or singing as a way to transcendence. And I have brought all of what I learned 
from the listening of New Orleans blues, jazz and gospel and the making of gumbos and jambalayas and red beans and rice to the making of poems and essays. I am what I am, for better or worse, as a writer, at least partly because of what I learned from the black culture of New Orleans.

Louis Armstrong famously signed his letters "red beans and ricely yours," and the smell of red beans cooking still brings to mind his gravelly voice, the sound of sloppy jazz and the sense of triumph over adversity. Red beans and rice was the poor man's dish, and poor we were. My mother cooked beans and rice, spiced with cayenne and seasoned with salt pork, several times a week. About twenty years ago, when I was a budding poet, I sent a poem to Rita Dove for a journal she was editing. The poem, called "Mother's Red Beans and Rice," was written around my mother's inventive ways of cooking red beans during a time when money was scarce, and involved her putting not only onions, green pepper and salt pork in with the beans, but also her blood, her sorrow at the troubled marriage she had made, and her lost desire for the man she never married.

"We're filled up for that journal," Rita Dove wrote back, "but I'm also an editor for Callaloo. Would you allow me to publish your poem there?"

I knew Callaloo published only writers of color. Maybe they'd changed the rules, I thought. Maybe Callaloo was now accepting work from whites. It was a fine journal.

"Great," I wrote back. "Go ahead."

Two weeks later she wrote back again (these were the days before email) to say she had a delicate question to ask. She had assumed I was black. Was I?

My heart sunk. I was still a young poet lusting for publication.

"No," I wrote back. "I'm not black."

The letter I wrote her was a long one in which I elaborated on the importance of New Orleans' black culture to me. I went on at length about music and food and such. She published the poem in TriQuarterly.

What I didn't tell her in my long letter was that I also came from a family of racists. I didn't tell her that of my entire extended family only my mother was not racist. I didn't tell her that my father, who was manager of a New Orleans bowling alley, had forced a black 
couple to leave in the early sixties when they tried to enter. Or that my younger sister, who had witnessed this drama, had saved it as a treasured memory of our father as a hero. I didn't tell her about my Catholic aunt who prayed the rosary every day but complained about the niggers around the block. I didn't tell her about my deafmute Cajun grandparents who thought it amusing to name their black cat nigger. I didn't tell her that I had learned, from these grandparents, their sign for nigger. It was very like the sign we had learned for dirty-you crook your index finger and drag it underneath your nose. I didn't tell her, because it hadn't happened yet, that everyone in the family outside of my mother and myself would vote for David Duke when he ran for governor. I didn't tell her that my family, whose roots go back two hundred years in Louisiana, had owned a working plantation, and slaves. I didn't tell her that while doing genealogical research I had found an inscription on a tombstone stating that no black person might be buried in that ground, and I didn't tell her about the hatred that sometimes shaped my people.

I come from a working class family. Neither my father nor my mother went to college. My father was an alcoholic who died of cirrhosis. There are many other drunks, addicts, and criminals in my family. I am a memoirist, and had no trouble writing about the drunks and criminals when I wrote my memoir Swamp Songs, about growing up in New Orleans. But race was another matter. It seemed such a huge thing, and I didn't know how to introduce it into the familial story of self-destruction and salvation I wanted to tell without having it dominate the whole thing.

When my great uncle agreed to be interviewed by me a few years ago for Swamp Songs, we spent a wonderful day talking. My uncle is an amateur singer with a rich and velvety voice, though it has become somewhat thinned with age. He sang Too-Ra-Loo-Ra-Loo$\mathrm{Ra}$ for me, told me stories about the Korean war that made me cry, and stories about my mother as a girl that made me laugh. But after six hours of taping, he started in with the niggers and the jews and how they had "ruined" New Orleans. I immediately stopped taping, and excused myself to go to the bathroom. I sat in the bathroom, looking at the walls, knowing I could not write the story I had wanted to write.

I never listened to the tape and I never wrote about any of the stories my great uncle told me because they all seemed tainted. I 
would have to figure out how to write a family story that included race some other time, I told myself.

One Sunday afternoon, when my sister was very young and I just a bit older, she pointed to a black family in Audubon Park where we were picnicking.

"Look at the burned people," she said.

My father found her remark amusing, but my mother was horrified, and hurried to correct her.

"They're not burned, sweetheart, they just have a different color skin."

My sister wrinkled her nose, still unsure. She smiled up at my father, and he smiled back at her, rubbing her head. I looked at them both as if they were aliens.

Many years later I had a phone conversation with my sister in which she bragged that she was racist-she used the very word-and that she was raising her children and grandchildren to be racist. She gave me some painful examples, which I will not repeat here, of the words she was teaching her grandchildren to call people of color.

"That's how daddy was," she explained, "and I always wanted to be like daddy."

By then I knew better than to argue with her, but I thought back to that day when, unsure of how to respond to something that she didn't understand, she invented a story that comforted her: the people next to us were black because they were burned. Apparently my mother's rational explanation was not enough to counter the more interesting story she had told herself about their skin color.

In fact, my sister was right that the "burned people" were burned, as well as whipped and beaten, but of course the conditions of slavery and its aftereffects had nothing to do with why their skin was another color. Truths often hide in the misshapen jungle of narratives or metaphors we construct to understand something we perceive as other. Sometimes I think it might be more fruitful to understand our early attempts at making sense of the world the way we understand dreams, or poems: as messages from deep within us. We have to have the courage to enter them to find where our own fears have influenced the construction of a particular metaphor or story.

Why did my sister see the black family as burned? Could she herself have been burned? Was she burning in some way? In fact 
we would learn, many years later, that a family friend was, at that time, sexually abusing her. Her world was burning, a burning she didn't understand, and the black family may have triggered the idea of burning in her.

Then again, having been given no context for understanding skin color, it is just as likely there is a simpler, or additional explanation: white skin, she might have concluded, was normal, like the white bread we ate every day, and black skin was deformed in some way, burned, like the bread when we left it too long in the toaster. As she grew older she was inducted into the guild of racism by my father, whom she adored. If she could please him by sharing his views, she would do it.

I have been trying to work my way up to saying a few words about hurricane Katrina and the issue of race. It's difficult for me to talk about race specifically with respect to Katrina because there was so much personal family grief and tragedy surrounding the hurricane: the unexpected death of a brother, the destruction of my brother's home as well as that of two of my uncles, including the elderly uncle who sang Too-Ra-Loo-Ra-Loo-Ra, the displacement of my mother for a month, and the damage to her home, my childhood home. About a foot of water came into the house, she lost most of the shingles and windows and had five trees knocked down in her yard. All the food in her refrigerator and freezer was ruined, and would stay, stinking and rotting, until I came a month later to help her remove it. Her next-door neighbor had a tree uprooted and turned nearly upside down by Katrina's winds, which then hurled the tree into the center of the house.

I went home to New Orleans after Katrina and just before Rita to help my mother. I learned to use a chainsaw to cut up the fallen trees, helped put a tarp up on her roof (which Rita blew off a few days later), and moved the black bags filled with rotting food to the front yard where the city would pick them up some weeks later. I saw and smelled with my own eyes and ears the devastation.

In the evenings my mother and I watched, over and over, the images that were still being shown of the mostly black families trapped on the tops of houses, and we watched the torture that seemed to go on forever of the poor families who could not afford to evacuate and had to suffer the slow response of the government. 
It was at once surreal and familiar, like the times when I was much younger and we used to watch scary movies together late at night, only this time I was not comforted, as I had been as a child, by my mother's presence and by the sense that all the scary stuff would go away when we turned off the television.

We watched, we witnessed, we took it in.

When I was first born my family was poor, and we lived on the edge of the ninth ward in New Orleans, the area that suffered deeply from the floods of Katrina. A few years ago, when I was writing Swamp Songs, I wanted to go with my mother to see the house where we used to live.

"Oh Sheryl," she said, "let's not. That neighborhood is all black now," as if that settled the question. This from a woman I would not consider a racist. This from a woman who had said to me, when I was seeing a black man, "He will always be welcome in my home. I don't know what your brother will think, but I will welcome him."

I could have challenged my mother on her comment about the neighborhood, but instead I went by myself. The truth is my mother is old, New Orleans has a murder rate that is one of the highest in the nation, and my mother knows that these areas are not safe ones for women of any color to travel alone. My mother is not so unlike many other white New Orleanians who love their city and are wellmeaning, but who are sometimes at odds with themselves about the question of race. We are not all racists, but my mother's generation of working class whites were mostly raised by racists, and they had to find their own way out of that jungle. Sometimes, having had no meaningful mentorship, they stumble, sometimes they get lost, but they often find the way again.

My mother is proud of being from New Orleans; she owns a fantastic collection of New Orleans books and music-mostly black musicians-and she goes to Mardi Gras, the Jazz Fest and indeed most of the festivals celebrating the culture every year, and has for the last seventy-five years. She has an unholy and sometimes irritating pride in the city. I can see now that not only is she in mourning for our birth city, but that she has had something stripped away in her by having had to witness this festering wound at the heart of a city she loves so much, this wound that houses the culture of the city, its blues and jazz and spicy food, its colorful personality. She can't say, as she did so many years ago, oh Sheryl, it's all black, let's 
not go, because it's there, every day, in the papers and on the television for everyone to see.

My mother didn't much like it when I wrote about the criminals and alcoholics in our family, and she is as shaken now seeing the city's hypocrisy exposed in such a public way. I don't wish my mother, who is old and frail, to suffer, but I am of the opinion that truth is a good thing, no matter how much it hurts. What about the children, she asked when I published my memoir. Indeed, what about the children? Don't we owe our children the truth?

New Orleans has always been a city of extremes, beginning with its location at the very end of the Mississippi, the very bottom of the bottom of the United States. It is already losing almost thirty square miles of land a year due to environmental degradation, so it's not an exaggeration to say it's falling off the edges of the country. Its people have always seemed larger than life, their appetites for food, drink, music, sex and fun, not to mention drugs, violence and murder genuinely spectacular. The drama and devastation of hurricane Katrina is so surrealistically, unbelievably extreme however, that it seems to me to have crossed some line, and to have rendered New Orleans and its inhabitants, almost, as freaks in a freak show.

The reason we like to go to freak shows is because there is such a clear differentiation between the freaks and us. If they are the freaks, we are not. We need to resist the temptation to see New Orleans and New Orleanians as freakish. We need to see that there is much of the heart and soul of our country that resides in this city, and that it is, in some ways, a microcosm for what goes on in the rest of our country.

We are all New Orleanians. We are all racists to some extent, we are all responsible for the housing conditions in New Orleans, and we are all responsible for the slow response of our government to the floods. We elected the government that led the response.

When I left my mother after Rita, she said goodbye to me with tears in her eyes, and stuttered out something I never thought I would ever hear her say, indeed it seemed as if she was speaking another language, one she hardly knew.

"I think, maybe, Sheryl," she said, "I mean I don't think, those poor people, they've lost everything, I can't complain..." 
She looked around at her ruined living room, carpet ripped up, the books swollen with water, the moldy furniture, the boarded up windows.

"I think I might have to move away from New Orleans. I don't think I can take another hurricane." She gave me a hug and pushed me out the door, as if she didn't want me to think too much about what she had said.

I hope my mother doesn't move. I hope everyone who has leftand some estimates put that at $80 \%$ of the city-returns. I hope that we find some way of looking bravely and responsibly at this situation we have caused, and that we find some way of not being blinded by the sight of the gaping wounds and flaws of this laboring, beautiful beast of a city.

At my brother's funeral my entire family was in mourning and still in a bit of shock; preceded in death by my father and another brother, Andre was the third of the men in our immediate family to have died young. My sister and I had no father and now we had no more brothers.

Andy, my brother's black employee and friend, was the first to arrive at the funeral, and the last to leave. He was the only black present, and seemed mostly lost in his own sorrow, crumpled off to the side, sobbing, during most of the service. It was my sister, my racist sister, who, seeing his grief, walked up to him and held and kissed him for what seemed like a long time, holding his face, looking into his eyes. I was too far away to hear what they were saying, but I could see they were both crying.

Andy wasn't invited afterwards for gumbo, beer and a ritual playing of Andre's favorite Lynyrd Skynyrd songs. 